\title{
Variations of Ornithine Transcarbamylase Activity in Five Different Breeds of Chickens
}

\author{
Soichi TsujI \\ Faculty of Agriculture, Kobe University, Kobe-shi 657 \\ (Received February 21, 1974)
}

\begin{abstract}
Kidney ornithine transcarbamylase (EC 2.1.3.3) activities of chicks of five different breeds of chickens were compared in this study. Ornithine transcarbamylase (OTC) activities of California Gray, New Hampshire, Rhode Island Red, White Plymouth Rock and White Leghorn A line, were all within a range of 0 to 50 units, and rarely exceeded 10 units. Differences of OTC activities were slight among these five breeds, of which California Gray showed the lowest level of less than one unit. In White Leghorn B Line, extremely high activities of OTC were found, where $25 \%$ of the population showed 140 to 290 units and the remaining $75 \%$ showed 0 to 50 units. This distribution is apparently bimodal and would imply genetic control of OTC activity in the chicken.
\end{abstract}

The enzymes involved in urea biosynthesis are nearly all absent in avian liver ${ }^{14,22}$ and the dietary supply of arginine is essential for both young and adult chickens. In spite of this dependency on dietary arginine, the amount of this amino acid that chicks require in their diet has been shown to vary widely ${ }^{18)}$. HutT and NEsheim selected two lines of White Leghorn breed which differ in the ability to grow and survive on diet deficient in arginine ${ }^{4,5,17)}$. NESHEIM and GARLiCH uncovered the difference in response to the arginine deficiency between the two lines depending on the different response of kidney arginase (EC 3.5.3.1) activity to the arginine deficiency ${ }^{16)}$. However, they gave no information of the enzyme properties of the two lines and did not reveal the regulatory mechanism of changes either in the activity or in the synthesis of the kidney arginase. Two types of arginase in the liver of chicks have been known; one is ureoteric type and the other is uricoteric type ${ }^{19}$. As is the case of arginase, many variant types of the enzymes of ornithine-urea cycle have been found in man with some metabolic disorders $1,10,13$.

The experiment reported here was made in an attempt to provide the evidence for the exsistence of genetic variants of or nithine transcarbamylase (OTC) (EC 2.1.3.3) in the chicken kidney.

\section{Materials and Methods}

\section{Chicks}

Two days old chicks of five different breeds, i.e., California Gray, Rhode Island Red, White Plymouth Rock, New Hampshire and White Leghorn were used in this study. White Leghorn breed contained two lines. One line named as "White Leghorn A" has been maintained by closed mating system since 1963 at Hyogo Prefectural Experiment Station of Animal Husbandry. The other line named as "White Leghorn B" was bred by Ishii Layer Research Farm. Relation between the two lines is not clear.

Jap. J. Zootech. Sci., 45, (9): 502-509. 502

1974. 9. 


\section{Preparation of Homogenates}

Freshly excised kidney homogenized at $4^{\circ} \mathrm{C}$ with the POTTER-ELVEHJE glass homogenizer equipped with a Teflon pestle in the presence of cetyl-trimethyl-ammonium-bromide (CTMAB) in the ratio, $1.0 \mathrm{~g}$ of kidney to $19.0 \mathrm{ml}$ of $0.1 \% \mathrm{CTMAB}$ and the homogenate was centrifuged at 3,000 rpm for 10 minutes. The supernatant was used as the enzymatic solution. The enzyme assay was carried out immedietaly after the preparation of the sample.

Subcellular fractionation was carried out by the method of HoGEBoom ${ }^{2}$.

\section{Assay of OTC}

The assay condition for OTC of chick kidney was determined from the kinetic studies as described under the heading: Results. For the enzyme assay the reaction mixture $(1.5 \mathrm{~m} l)$ contained $40 \mu$ moles L-ornithine hydrochrolide, $50 \mu$ moles tris-hydroxymethyl-aminomethane (Tris)- $\mathrm{HCl}$ buffer ( $\mathrm{pH}$ 7.5), $5 \mu$ moles dilithium carbamyl-phosphate, and enzyme solution. The volumes of the enzyme solution were changed from 0.1 to $1.0 \mathrm{~m} l$ according to the enzyme activity. Carbamyl-phosphate was dissolved just before use. The reaction was started by the addition of carbamyl-phosphate, allowed to continue for 20 minutes at $37^{\circ} \mathrm{C}$, and then stopped by the addition of $0.5 \mathrm{ml}$ of $10 \%$ trichroloacetic acid. The clear supernatant solution obtained by centrifugation was analyzed for citrulline according to the method of HunNINGHAKE and GrISOLIA $^{31}$. The assay system having no $\mathrm{L}$-ornithine was served as a zero time control.

One enzyme unit was defined as the amount of the enzyme that catalyzes the formation of $1.0 \mu$ moles of citrulline in one hour at $37^{\circ} \mathrm{C}$. The specific activity was expressed as unit per $\mathrm{mg}$ of protein.

\section{Protein Determination}

Protein was determined by the method of LOWRY et al. ${ }^{11}$, using crystalline bovine serum albumin as a standard.

\section{Results}

\section{Distribution of OTC in the Chick Organs}

Table 1 shows the results on the distribution of OTC in chicken organs. The enzyme activity was mainly found in the kidney of the chick and the activities in other organs were extremely lower than that of the kidney.

Table 1. Distribution of ornithine transcarbamylase in chick tissues

\begin{tabular}{lr}
\hline Tissue & OTC activity \\
\hline Liver & $0.8 \pm 0.3$ \\
Kidney & $142.6 \pm 45.4$ \\
Heart & $0.2 \pm 0.1$ \\
Stomach & $0.6 \pm 0.2$ \\
Intestine & $0.4 \pm 0.4$ \\
Breast Muscle & $0.4 \pm 0.1$ \\
Brain & $0.8 \pm 0.2$ \\
Pancreas & $1.0 \pm 0.2$ \\
\hline
\end{tabular}

* $\mu$ moles citrulline formed $/ \mathrm{hr} / \mathrm{gm}$ wet wt.

Value $=$ Mean \pm standard error of five chicks of White Leghorn $B$ line 
Table 2. Subcellular distribution of ornithine transcarbamylase in chick kidney

\begin{tabular}{lrrr}
\hline \multicolumn{1}{c}{ Fraction } & OTC activity* & $\%$ & specific activity** \\
\hline Initial homogenate & $136.5 \pm 24.6$ & 100.0 & $4.3 \pm 0.9$ \\
Supernatant & $2.6 \pm 1.4$ & 1.9 & $0.2 \pm 0.1$ \\
Mitochondria & $31.7 \pm 3.9$ & 23.2 & $22.6 \pm 2.6$ \\
Cell debris & $90.9 \pm 11.7$ & 66.6 & $6.2 \pm 0.7$ \\
\hline
\end{tabular}

Value $=$ Mean \pm standard error of five chicks of White Leghorn $B$ line.

* $\mu$ moles citrulline formed $/ \mathrm{hr} / \mathrm{gm}$ wet $\mathrm{wt}$.

*** $\mu$ moles citrulline formed $/ \mathrm{hr} / \mathrm{mg}$ protein.

\section{Intracellular Distribution of OTC in Chicken Kidney}

The intracellular distribution of OTC in chicken kidney is shown in Table 2. The enzyme activity was observed in all fractions of the chicken kidney, but mainly found in mitochondrial and nuclear residual fractions. The specific activity of mitochondrial fraction was the highest among three fractions.

\section{Some Properties of OTC and the Enzyme Assay Condition}

Under the enzyme assay conditions employed, the kidney of White Leghorn B line chick used in this study had OTC activities of 100 to 150 units. The kidney was homogenized at $4^{\circ} \mathrm{C}$ in distilled water, and freezing and thawing were carried out. The crude extract was centrifuged at $10,000 \mathrm{rpm}$ for 10 minutes and cell-free extract was used for kinetic study.

The specific activity of the cell-free extract was 0.53 unit, and as shown in Fig. 1 , the optimum $\mathrm{pH}$ for the reaction was found to be about 7.5 with $\mathrm{Tris}-\mathrm{HCl}$ buffer, whereas the optimum $\mathrm{pH}$ of about 6.5 was observed with pottasium-phosphate buffer and the enzymatic activity was considerably inhibited with phosphate ion.

The Michazlis constants which have been determined for the extract are shown in Fig. 2 and Fig. 3, the $K m$ value with Tris- $\mathrm{HCl}$ buffer ( $\mathrm{pH} \mathrm{7.5)}$ were $2.6 \times 10^{-8} \mathrm{M}$ for $\mathrm{L}$-ornithine and 4. $6 \times 10^{-4} \mathrm{M}$ for carbamyl-phosphate.

From the results of this study, the assay condition of chick kidney OTC was determined.

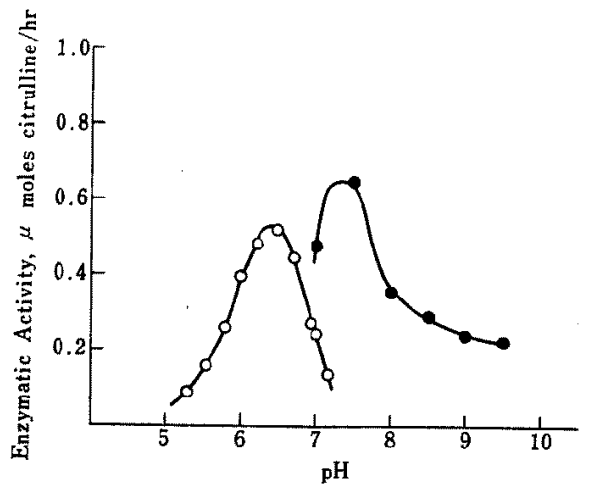

Fig. 1. Effect of $\mathrm{pH}$ on the initial velocity of citrulline synthesis by ornithine transcarbamylase in $0.03 \mathrm{M}$ Tris- $\mathrm{HCl}$ buffer (•) and $0.03 \mathrm{M}$ pottasium-phosphate buffer $(0)$ at $37^{\circ} \mathrm{C}$ 
Chick Kidney Ornithine Transcarbamylase

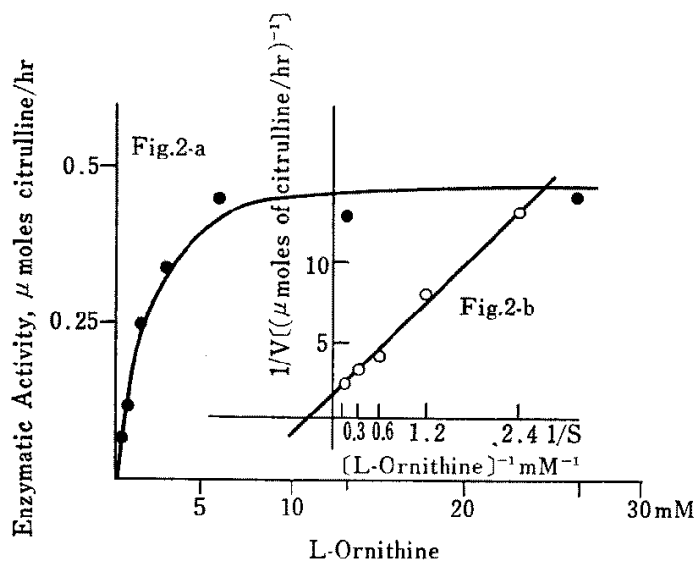

Fig. 2-a. Effect of L-ornithine concentration on the activity of ornithine transcarbamylase from chick kidney.

Fig. 2-b. Double reciprocal plots of the velocity of the reaction against the concentration of L-ornithine for chick kidney ornithine transcarbamylase.

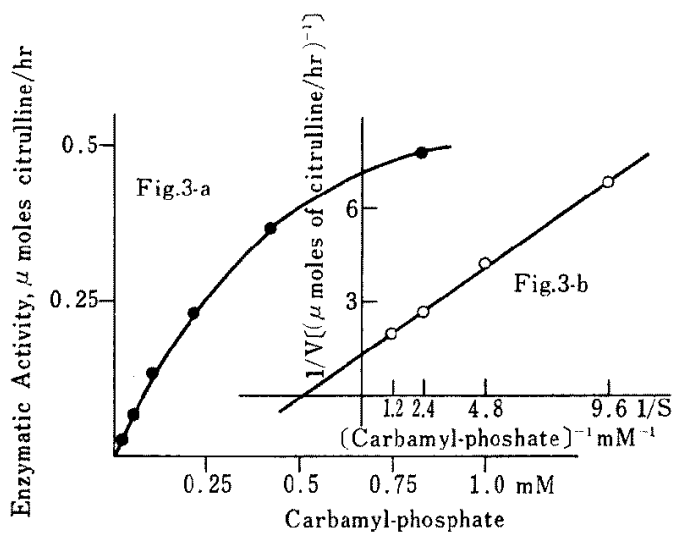

Fig. 3-a. Effect of carbamyl-phosphate concentration on the activity of ornithine transcarbamylase from chick kidney.

Fig. 3-b. Double reciprocal plots of the velocity of the reaction against the concentration of carbamylphosphate for chick kidney ornithine transcarbamylase.

\section{Variations of OTC Activity between Chicks of Some Breeds}

As shown in Fig. 4-a and 4-b, OTC activities of most of the chicken breeds reported here were extremely low and less than 30 units. In these breeds, the lowest level of the enzymatic activity was found in California Gray and was less than 10 units. The enzymatic activity of New Hampshire breed was less than 20 units. Chicks having the enzyme level 
ranged from 10 to 20 units were only 2 per cent and in the remainders it was less than 10 units.

In contrast to the above two breeds, the enzyme activity of Rhode Island Red breed was considerably high and 24 per cent of the chicks had the levels from 10 to 20 units. White Plymouth Rock chicks having the enzyme activity ranging from 0 to 10,10 to 20 , and 20 to 30 units consisted of 58,30, and 12 per cent of the breed, respectively. The histogram of the enzyme activity of White Leghorn $A$ line was shown in Fig. 4-b as a typical line of White Leghorn breed. The enzymatic activity of White Leghorn A line was higher than those of other four breeds and the chicks having the enzymatic activity from 0 to 10,10 to 20,20 to 30,30 to 40 , and 40 to 50 units consisted of $60,20,10,5$, and 5 per cent of the line, respectively. The level of OTC in the chick kidney was extremely low.

On the other hand, White Leghorn $B$ line had extremely high activity of the enzyme and the levels was ten to twenty times as high as that of the other breed. The histogram of the enzyme level of White Leghorn $B$ line showed that the populations were consisted of two phenotypically different groups; the low activity group and the high activity. The distribution of the frequency of the enzymatic activity of the former group resembled with that of White Leghorn A line. In the latter group, the enzymatic activity was very high and the activities varied from 140 to 290 units and the mode of the distribution was found at approximately 200 units. The chicks of low activity group consisted 75 per cent and those of the high activity group consisted 25 per cent of the $B$ line.

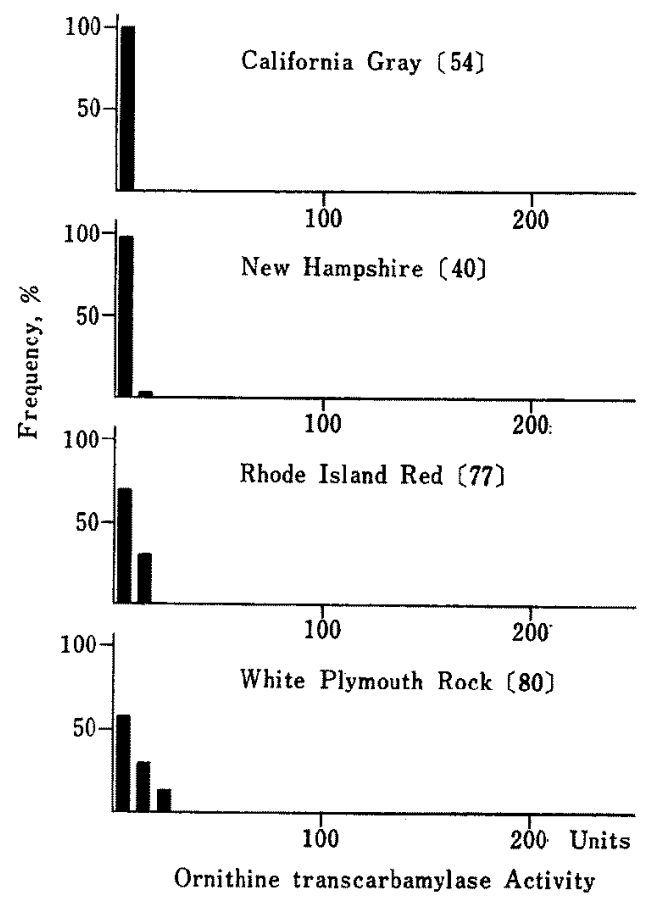

Fig. 4-a. Histograms of ornithine transcarbamylase level of four chicken breeds 


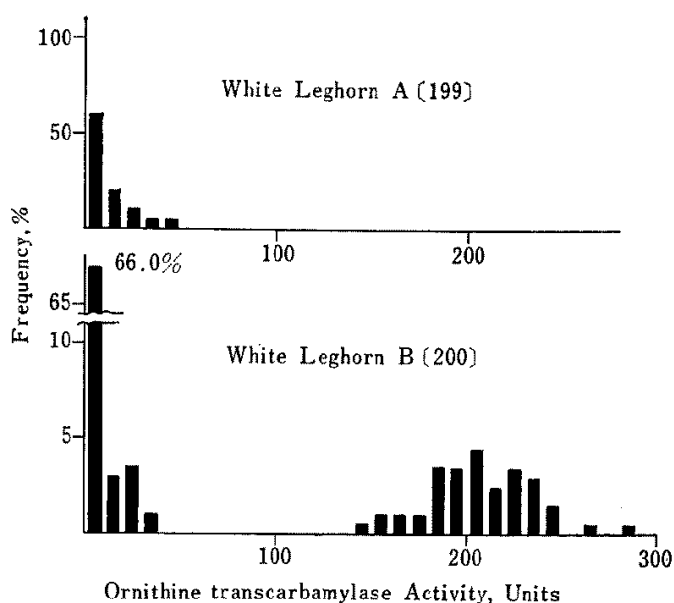

Fig. 4-b. Histograms of ornithine transcarbamylase level of two different White Leghorn lines

\section{Discussion}

There are a few reports concerning OTC of chicken organs and it is indicated that the activity of the enzyme is extremely low in the chicken kidney, though the enzymatic activity between different chicken breeds yet to be compared.

In this study, some variations of the activity of OTC were observed in different chicken breeds. In most of the chicks the enzymatic activities of the kidney were less than 10 units, and were in good accord with the levels presented by TAMIR and RATNER ${ }^{22 !}$. It was found that the enzymatic level was especially low in California Gray. In the further study concerning this breed, the enzyme solution was concentrated by precipitating with acetone at $0^{\circ} \mathrm{C}$, and after centrifugation the precipitate was taken up in a twentieth part of initial volume with $0.05 \mathrm{M} \mathrm{Tris}-\mathrm{HCl}$ buffer, $\mathrm{pH} 7.5$ prior to the determination of enzymatic activity. By this procedure, it was revealed that the enzymatic activity of this breed was less than one unit or the breed was practically lacking the enzyme.

In contrast to the low activities in California Gray, the extremely high activity of the enzyme was found in the kidney of chicken of White Leghorn $B$ line. The distribution of frequency of the enzymatic activity of the B line was distinctly bimodal, where the activities of the enzymes were high in one fourth and low in three fourth of the population. The enzymatic activities of the former group ranged from 140 to 290 units, which were $1 / 25$ to $1 / 50$ of those of bovine liver ${ }^{12)}$. The average level of the enzymatic activity of the latter group was about 10 units. When the analytical procedure was carefully standardized, this remarkable variation remained unaltered whether the chicks were fed or not. The persistence of such variation suggested that the renal OTC activity was genetically regulated. In many cases, the deletion of the enzymes is due to partial change of the structure gene, which results in the partial change of the sequence of amino acid of enzyme, including the alteration of the property and activity of enzyme ${ }^{7}$. These alterations may be also occurred with the appearance of the new enzymes.

In the present study it was demonstrated that OTC activity was the highest in the chick kidney and that of the other organs was negligible. In other ureoteric animals, the enzymatic 
activity was mainly found in their livers ${ }^{32}$.

Highly specific activity of the enzyme was concentrated in the mitochondrial fraction of the chicken kidney, and might correspond with the similar enzyme found in hepatic mitochondria of the rat ${ }^{14)}$.

The properties of OTC of White Leghorn B line chick which had high activity were determined with cell-free extract of the kidney. The optimum $\mathrm{pH}$ for the reaction of the enzyme was found to be about 7.5 with $\mathrm{Tris}-\mathrm{HCl}$ buffer in the chicken, and in this respect it markedly differed from that of the enzymes of other species ${ }^{6,8,9,12,201}$. The enzyme displayed normal Michaelis-Menten kinetics and the $K m$ value calculated from the slope of reciprocal plots for L-ornithine was $2.6 \times 10^{-3} \mathrm{M}$ and for carbamyl-phosphate was $4.6 \times 10^{-4} \mathrm{M}$. Species specific difference of $K m$ value for carbamyl-phosphate was observed $6,9,15,30,21$.

Clarification of the mode of inheritance and the physiological roles of the enzyme of high activity would be important problems in future studies.

The author wishes to thank Professor Dr. T. Fukushima for his useful discussion and stimulating comments. The author also thanks Ishii Layer Research Farm, Ishii-cho, Tokushima-ken, Japan, for the supply of chicks to carry out this work.

\section{References}

1) Allan, J.D., D.C. Cusworth, C.E. Dent, and V.K. Wilson, Lancet 1: 182-187. 1958.

2) Hoge воом, G.H., Methods in Enzymol (Ed. N.O. Karlan) Vol. 1 16. Acad Press. New York. 1955.

3) Huninghake, D., and S. Grisolia, Anal Biochem 16:200-205. 1966.

4) Hutt, F.B., and M.C. Nesheim, Can J Genet Cytol 8: 251-259. 1966.

5) Hutt, F.B., and M.C. Nesheim, Can J Genet Cytol 10: 564-574. 1968.

6) Joseph, R.L., E. Baldwin, and D.C. Watts, Biochem J 87: 409-417. 1963.

7) Kimura, M., and T. Ohta, Protein, Nucleic acid and Enzyme (in Japanese) 17: 401-413. 1972.

8) Klezkowski, K., and P.P. Cohen, Arch Biochem Biophys 107: 271-278. 1964.

9) Lasshley, E. J., and R.W. Bernlohr, Biochim Biophys Acta 167: 574-554. 1968.

10) Levin, B., J.M. Abraham, V.G. Oberholzer, and E. AnnBurgess, Arch Dis Childh 44: 153-161. 1969.

11) Lowry, O.H., N. J. Rosebrough, A.L. FARR, and R. J. Randall, J Biol Chem 193: 265275. 1951.

12) Marshall, M., and P.P. Cohen, J Biol Chem 247: 1641-1653, 1972.

13) McMurray, W.C., F. Mohyudin, R. J. Rossiter, J. C. Rathbun, G. H. Velentine, S. J. Koegler, and D.E. Zarfas, Lancet 1: 138 . 1962.

14) Mora, J., J. Martuscelli, J. Oriz-Pineda, and G. Soberon, Biochem J 96: 28-35. 1965.

15) Nakamura, M., and M.E. Johnes, Methods in Enzymol (Ed. in N. O. Kaplan) Vol. 17-A: 286-294. Acad Press. New York. 1970.

16) Nesheim, M.C., and J.D. Garlich, J Nutr 79: 311-317. 1963.

17) Neshem, M.C., and F.B. Hutr, Science 137: 691-692. 1962.

18) Nesheim, M.C., Fed Proc 27: 1210-1214. 1968.

19) Rossi, N., and E. Grazi, Eur J Biochem 7: 348-352. 1969.

20) Rogers, P., and G. D. Novelli, Arch Biochem Biophys 96: 398-407. 1962.

21) Reichard, P., Acta Chem Scand 11: 523-536. 1957.

22) Tamir, H., and S. Ratner, Arch Biochem Biophys 102: 249-258. 1963. 


\title{
ニワトリ腎臓 Ornithine transcarbamylase の品種による
}

\author{
差異について \\ 过荘一 \\ 神戸大学農学部, 神戸市 657
}

㽷素合成系酵素群はアンモニアの排泄型との関連にお いて生物の種によりその活性に大きな变異がある。鳥類 ではその進化の過程で尿酸排泄型への転換とともにその 旰䁍でのこれら醉素群の欠損が生じ，フルギニンが必須 フミノ酸となっている。とるで，著者はこの尿素台成 系酵素群の一つである Ornithine transcarbamylase (OTC) の遗伝変異体乙思われるきわめて活性の高い酵

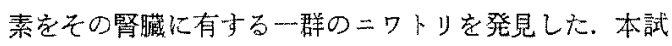
験に供した 5 品種, California Gray, New Hampshire, Rhode Island Red, White Plymouth Rock, White Leghorn の上ナともその腎臓の OTC 活性は弱く, 大
部分の個体が 10 unit (1 unit: $1 \mu$ moles citrulline/ $\mathrm{hr} / \mathrm{gm})$ 以下であった。 またてそれらのうらで最も活性 の高い個体でも 48 unit にすぎなかった。とこで， White Leghorn 種の一䓱統 (WL-B) はこれらの活性の 低いニワトリとは異なり 290 unit もの活性定示す個体 が存在した。その出現頻度の度数分布図岁作る己明らか 飞 Bimodal な分布を示し，2つの異なる活性索有する 集団に区分できた，その高い活性を有少る集団は140か

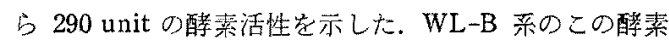

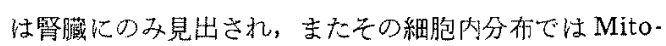
chondria k繥合しているすのと推定された. 